\title{
Identification of Bird Species Used to Make a Viking Age Feather Pillow
}

\author{
Carla J. Dove ${ }^{1}$ and Stephen Wickler ${ }^{2}$
}

\author{
(Received 24 July 2015; accepted in revised form 4 November 2015)
}

\begin{abstract}
A grave containing the remains of a wooden boat was discovered in 1934 under a low mound in a bog at Øksnes in the Vesterålen islands of northern Norway. The boat grave dates to the 10th century in the Viking Age, and grave goods placed in the boat include an iron axe, a cowhide in which the body was wrapped, and pillow remains consisting of feather stuffing and a wool textile cover. A microscopic analysis of the feathers from a subsample of the pillow fill identified three avian orders: Anseriformes (eider); Suliformes (cormorant), and Charadriiformes (unspecified gull). It was possible to make one species-level identification of Great Cormorant (Phalacrocorax carbo) and to narrow the gull types to the "white-headed" gull group. The sample was composed of a nearly equal mix of downy and pennaceous feather types. Downy feathers from gulls (Laridae) composed the majority of the material in this sample. While it is reported that feathers and down (assumed to be eider) were used in the Late Iron Age, this is the first successful attempt to identify bird species used in these materials and suggests that avian species identifications should be explored in other such burial items to enhance our understanding of human-wildlife interactions throughout Norse history.
\end{abstract}

Key words: northern Norway; Vesterålen islands; Viking Age; boat grave; pillow; birds; feathers; microstructure

RÉSUMÉ. Une fosse comprenant les restes d'un bateau en bois a été découverte en 1934 en bas de la petite butte d'une tourbière à Øksnes, dans les îles Vesterålen, au nord de la Norvège. La fosse remonte au dixième siècle de l'âge des Vikings et les objets funéraires placés dans le bateau comprennent une hache de fer, une peau de vache dans laquelle le corps était enveloppé et des restes d'oreiller constitués d'une garniture de plumes et d'une étoffe en laine. Un sous-échantillon de la rembourrure de plumes a été analysé au microscope, ce qui a permis d'identifier trois ordres aviaires : Anseriformes (eider), Suliformes (cormoran) et Charadriiformes (goéland non spécifié). L’analyse a également permis d'identifier une espèce de cormoran, soit le grand cormoran (Phalacrocorax carbo), et d'établir que les types de goélands appartenaient au groupe à « tête blanche ». L'échantillon était composé d'un mélange à peu près égal de types de plumes duveteuses et de plumes pennes. Les plumes duveteuses de goélands (Laridae) composaient la majorité de la matière de cet échantillon. Bien que l'on ait signalé que plumes et duvet (prétendument en provenance d'eiders) aient été utilisés vers l'âge du fer supérieur, il s'agit de la première tentative réussie d'identifier les espèces d'oiseaux utilisées dans ces matériaux, ce qui suggère que l'identification des espèces aviaires devrait être approfondie dans le cas d'autres articles d'inhumation afin de mieux comprendre l'interaction entre les humains et la faune au fil de l'histoire norse.

Mots clés : nord de la Norvège; îles Vesterålen; âge des Vikings; bateau-tombe; oreiller; oiseaux; plumes; microstructure

Révisé pour la revue Arctic par Nicole Giguère.

Резюме. Могила с останками в деревянной лодке была обнаружена в 1934 году в низкой насыпи в болоте у Øksnes на Вестероленских островах северной Норвегии. Захоронение датируется 10-м веком в эпоху викингов и вещи, помещенные в лодку включают железный топор, коровья шкура, в которую было завернуто тело и остатки подушки состоящей из шерстяной оболочки зполненой перьями. Выборка перьев из заполнения подушки была проанализирована микроскопически и три различных отряда птиц были определены по этим перьям: Гусеобразные (гага), Ржанкообразные (чайка) и Пеликанообразные (баклан). До вида удалось определить только баклана как большого баклана (Phalacrocorax карбо) и сузить тип чайки до «белоголовой» группы чаек. Выборка перьев состоит из почти равных объемов пуховых и контурных перьев. Пуховые перья чаек (Laridae) преобладали в составе выборки. Хотя сообщения о том, что перья и пух (предположительно гаги) использовались в позднем железном веке, это первая успешная попытка определить виды птиц из этих материалов, которая указывает на необходимость определения видов птиц и в других таких захоронениях для улучшения нашего понимания взаимотношений человека и диких животных в скандинавской истории.

${ }^{1}$ Corresponding author: Smithsonian Institution, Division of Birds, Feather Identification Lab, NHB E-600, MRC 116, Washington,

D.C. 20560, USA; dovec@si.edu

${ }^{2}$ Tromsø University Museum, Department of Cultural Sciences, University of Tromsø, N-9037 Tromsø, Norway; Stephen.wickler@uit.no

(C) The Arctic Institute of North America 
Ключевые слова: северная Норвегия; Вестероленские острова; Эпоха викингов; похоронная ладья; подушка; птиы; перья; микроструктура

Перевёл Сергей Дровецкий Sergei Drovetski.

\section{INTRODUCTION}

\section{The Øksnes Boat Grave}

During road construction at Øksnes vicarage in the Vesterålen islands, Nordland county, northern Norway (Fig. 1) in 1934, the remains of a wooden boat with an estimated original length of $8-10 \mathrm{~m}$ were discovered in a bog. Subsequent excavation revealed that the boat was buried toward the end of the Viking Age (AD 800-1050) in a low grave mound with a ring of stones placed around the outer margin. Although the bow and stern sections of the boat had been removed by earlier turf cutting, the keel, lower planking, and a frame in the midsection were preserved. Pieces of birch bark found under the boat planks indicate that the entire vessel had been covered by this material. The boat planks were fastened together or "sewn" with animal sinews in paired holes and caulked with twisted strips of wool thread. Although no skeletal remains were preserved, grave goods found in the boat included an iron axe, pillow remains consisting of feather stuffing and a wool textile cover, and animal hair interpreted as originating from a hide in which the body was wrapped. A radiocarbon date obtained from the textile (TRa-2953, $1100 \pm 25 \mathrm{BP}$ ) has a calibrated age range of AD 888-994 at two sigma. This age estimate agrees well with the typological dating of the axe found in the grave.

The boat grave excavation results were published by Gutorm Gjessing (1941), who described the find as a Norse male grave. However, he thought that the boat must have been built by the indigenous Sámi, since sewing with animal sinews is typical of Sámi boat building. He concluded that the Øksnes boat could be a Sámi vessel and the oldest known example of a Sámi boat made to order for a Norse community.

Although the basis for Gjessing's assertion as to the ethnic origin of the boat has been questioned (Wickler, 2010: 353), the Øksnes grave has a mixture of Norse and Sámi traits that illustrates the hybridized nature of ethnic identity and cultural interaction in the Vesterålen region during the Late Iron Age. The use of birch bark for wrapping the corpse and the presence of reindeer hides are typical of Sámi burials (Hansen and Olsen, 2014). Grave mounds and boat burials are typically Norse. Sewing of boats, in contrast, is a typical Sámi trait (Westerdahl, 2010). The blend of Norse and Sámi elements in the Øksnes burial challenges commonly held assumptions regarding material expressions of ethnicity and reveals the complexity of ethnic identity in this region. The favorable preservation conditions in the bog at Øksnes have also resulted in unique research material, and the burial has significant potential to increase

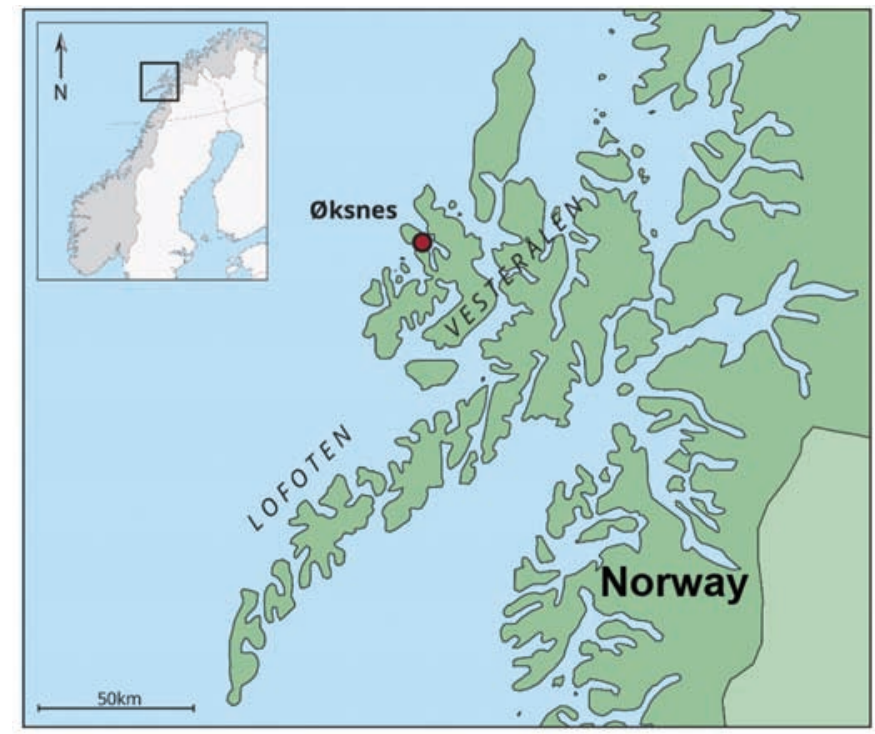

FIG. 1. Map showing the location of the Øksnes boat grave. Illustration: Adnan Icagic, Tromsø Museum.

our knowledge about settlement, society, religion, and ethnicity in Vesterålen during the Viking Age.

\section{The Øksnes Pillow}

A thick mass of feathers and down covered with a wool textile was found on the bottom of the boat during excavation of the Øksnes boat grave (Fig. 2). Clumps of animal hair found adhering to the textile were potentially attached to a hide in which the corpse was wrapped. The hair has been morphologically identified in a separate study as belonging to the Bovidae family of cloven-hoofed, ruminant mammals, and preliminary results suggest a close resemblance to domestic cow (Bos taurus) (Kirkinen, 2015).

Analysis of the wool textile by archaeologist Synnøve Thingnæs (2014) concluded that the binding, thread density, spinning direction, and density and thickness of yarn in the warp and weft indicate that all fragments originate from the same object, most likely a pillow cover. The textile is woven in diagonal $2 / 2$ twill with single-spun z-spin yarn, a weaving technique that was quite common in the Viking Age.

Although pillows and quilts of feathers and down are known from high-rank burials dating to the Late Iron Age in Scandinavia and Western Europe (Berglund, 2009), little or no effort has been made to identify the species of birds included in these items.

Microscopic feather identification techniques may be applied to identify species of birds used in ethnographic items (Dove and Peurach, 2002; Rogers et al., 2002; Dove et al., 2005). If proper diagnostic feathers are present in a 


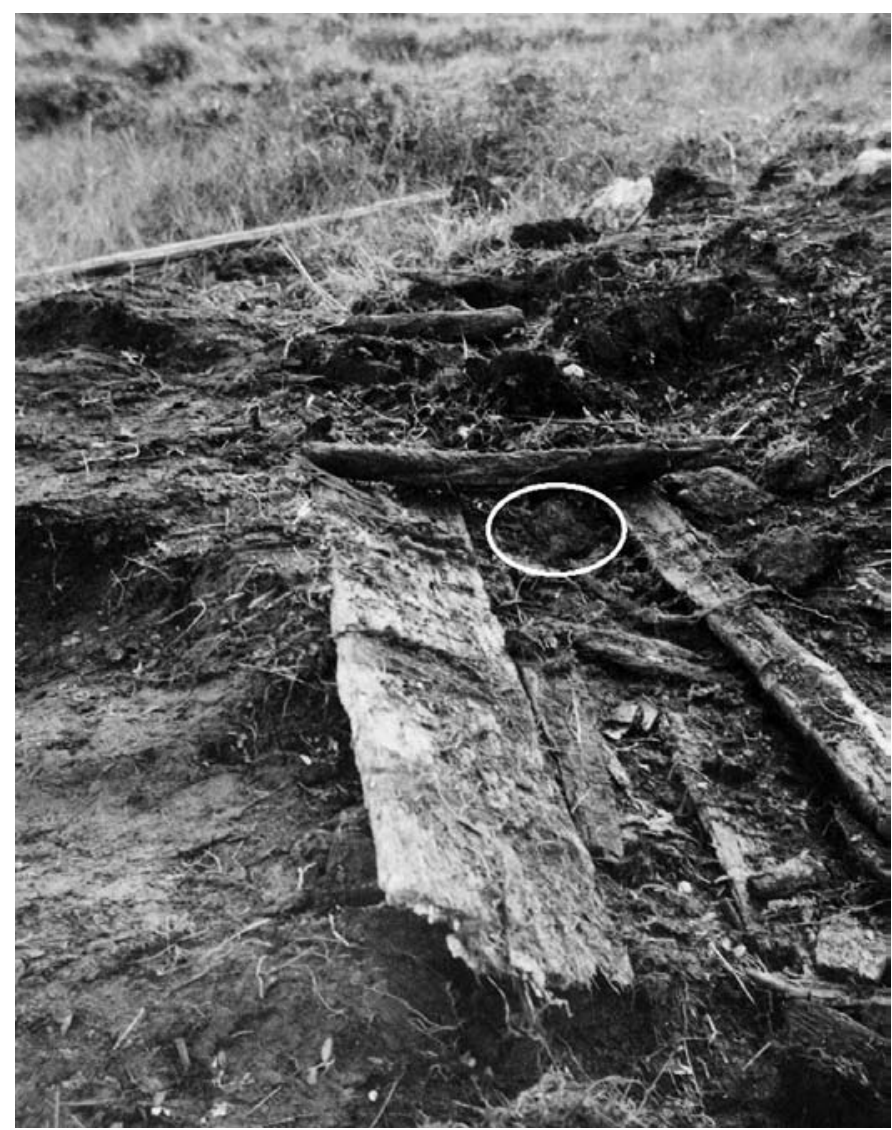

FIG. 2. Photograph of the Øksnes boat grave during excavation in 1934. The white circle indicates the location of the pillow remains. Photo: T. Soot-Ryan, Tromsø Museum.

sample, it may be possible to use the microscopic characters in the downy (plumulaceous) barbules to assign the feather sample to a particular group, order, or family of birds (Dove, 2000). Once the avian group is determined from the microstrucutre, species identifications can then be made if adequate pennaceous feathers are available to match with museum collections of voucher specimens. Knowledge of the species and its geographic distribution has helped researchers to determine the provenance of historical artifacts (Dove, 1998), identify bird clothing used in burials (Dove and Peurach, 2002), and understand the role and symbolism of birds to native cultures (Rabineau, 1980; Braun, 1995).

We analyzed a portion of the feather material found within the pillow recovered from Øksnes to determine the species or types of birds used in the making of this object. Identifying the species of birds used to make this pillow may provide insight into the lives of the inhabitants of Vesterålen and coastal northern Norway during the 10th century and will enhance our understanding of human-wildlife interactions throughout Norse history.

\section{METHODS}

The catalogued artifact (Ts. 3981b) is housed at the Tromsø University Museum, University of Tromsø,

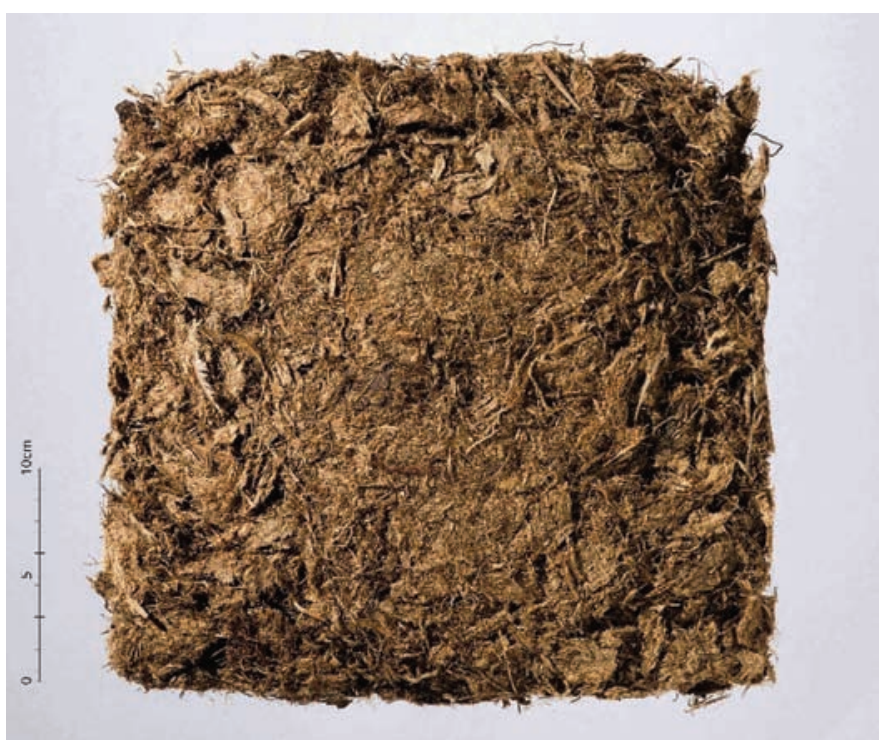

FIG. 3. Pillow fill mass from the Øksnes grave. Photo: Adnan Icagic, Tromsø Museum.

Norway, along with other artifacts from this study site. The complete pillow measures $30 \times 30 \mathrm{~cm}$ and is $4 \mathrm{~cm}$ thick (Fig. 3). A subsample measuring approximately $21 \times 14 \mathrm{~cm}$ was sent to the Feather Identification Lab of the Smithsonian Institution in Washington, D.C., for examination. Twelve microslides representing various areas from the downy feather pillow samples were prepared following methods outlined in Dove and Peurach (2002) for ethnographic research. Separate microslides were made from various parts of both the upper (side 1) and under (side 2) portion of the matted pillow subsample to determine whether multiple species were present. Microscopic preparation of fragile or brittle feathers is possible, but these types of samples usually cannot be washed because of the degradation of the material. All microslides were examined using a Leica ${ }^{\circledR}$ FS CB comparison light microscope at $100-400 \times$. Photomicrographs were taken with a Leica ${ }^{\circledR}$ DFC 290 HD digital camera using Leica ${ }^{\circledR}$ LAS Software Version 4.6.0 (C Leica Microsystems Ltd., CH 9435 Heerbrugg, Switzerland, November 2014). The microslides from this study are stored with the pillow item at the Tromsø University Museum in Norway.

In this study, feather samples were identified mainly by microscopic examination of the downy (plumulaceous) barbs that are located at the base of most contour feathers (Fig. 4), or grow in between feather tracts. Variations in the microscopic characters such as node shape, length of downy barbule, and pigmentation patterns may be used to assign an unknown feather sample to the taxonomic level of order or family if diagnostic characters are found in the sample. In this case, several fragments of pennaceous type feathers were also available for comparison with a collection of museum study skins. A combination of microscopic and macroscopic comparisons is typically used, together with circumstantial data and general bird distributions, to identify and corroborate designations of feathers to species level. 

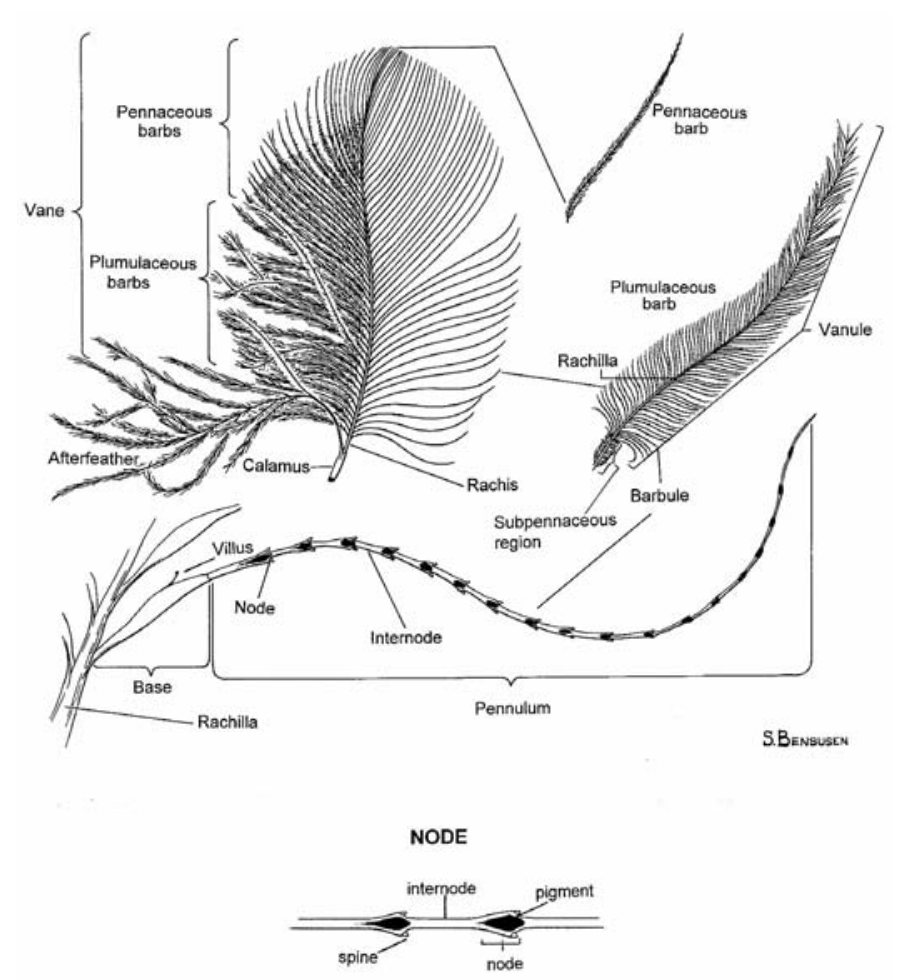

FIG. 4. Topography of a contour feather, with the various features used in microscopic feather identification.

We attempted to obtain mitochondrial DNA sequences (Cytochrome Oxidase I - COI) from six different pillow samples using various standard laboratory protocols, but without success. Because of the fragile and brittle nature and the age of these samples, we did not pursue more detailed molecular analysis after the initial failures.

\section{RESULTS}

The avian taxa identified in this study from the feathers associated with the pillow subsample (Table 1) represent three different orders of birds: Anseriformes (eider), Suliformes (cormorants), and Charadriiformes (unspecified gull) (Fig. 5A-F). It was possible to make one species-level identification of Great Cormorant (Phalacrocorax carbo) from the pillow sample because small fragments of the distal pennaceous feather were present in the sample (Fig. 6). Once the Order Suliformes was determined from the microscopic structure to be included in the pillow stuffing (Fig. 5E), loose feather fragments were compared to museum specimens for an exact species match to Great Cormorant (Fig. 6). We examined specimens of the two possible species of cormorant that occur in Europe-Great Cormorant (Phalacrocorax carbo) and European Shag (Phalacrocorax aristotelis). The iridescent back feathers of these two species differ in the color of the sheen and in the width of the terminal band. Great Cormorant feathers have a coppery sheen with a wide, irregular terminal black band, while European Shag feathers have a greenish sheen with a very narrow, well-defined black terminal band. The unknown pillow feather was determined to be a back feather because of the unique pointed shape, and the iridescent sheen was still visible on the partial feather from the pillow.

Anseriformes (ducks, geese, and swans) have diagnostic microscopic structures that easily allow identification of feather samples to this avian order. The nodes are usually few in number and, if present, are distinctly triangular in shape. These diagnostic nodes typically occur only at distal portions of the barbules, but there are consistent differences in the locations of these triangular-shaped nodes on barbules for some groups of waterfowl (Dove and Agreda, 2007). Although the microscopic characteristics of the waterfowl sample in this study could be narrowed to sea ducks and was most similar to eider (Somateria sp.; Fig. 5A-B), other possible species of sea ducks could not be ruled out on the basis of microstructure alone.

The sample from the pillow that was examined for bird identifications was composed of a nearly equal mix of both downy and pennaceous feather types. Downy feathers are the softest and known to have the best insulator properties. Downy feathers from gulls (Charadriiformes, Family: Laridae) composed the majority of the material in this examination. Nearly every microslide contained downy barbs of gull (Laridae) species (Table 1), while only one of the 12 samples contained downy barbs of a duck species (Anseriformes: Family: Anatidae).

Within Laridae, the microscopic feather characters of downy barbs of birds within the genus Rissa (kittiwakes) and Stercorarius (skuas and jaegers) differ from the Larus ("white-headed" gulls) and could be ruled out as possible species used in the making of the pillow. The genus Rissa typically has expanded and pigmented nodes that are much wider and more flared than those in the genus Larus. On the other hand, Stercorarius typically have very narrow, or much less expanded, pigmented nodes, and these nodes are visible throughout the entire length of the barbule (as opposed to mainly at the proximal portion, as in Larus). According to del Hoyo et al. (1996), eight species of gulls may occur in northern Norway: Mew Gull, Larus canus; Great Black-backed Gull, Larus marinus; Glaucous Gull, Larus hyperboreus; Iceland Gull, Larus glaucoides; Herring Gull, Larus argentatus; Lesser Black-backed Gull, Larus fuscus; Black-headed Gull, Chroicocephalus ridibundus; and Little Gull, Hydrocoloeus minutus. Although the downy feathers of gulls within the genus Larus are similar to each other in microstructure, there are subtle microscopic differences between the subgroups of "white-headed" and "black-headed" gulls (Dove, 2000) that were useful in narrowing the types of gulls in this study to those in the "whiteheaded" gull group. The Black-headed Gull and Little Gull were eliminated as possibilities because the microstructure of these species differs from that of the pillow samples by having many pigmented, expanded nodes that occur along most of the barbule. It is not possible to determine species-level identification for "white-headed" gulls in this case from the microstructure alone because there were no 
TABLE 1. Avian identifications of microscopic slides made from downy barbules sampled from the upper (side 1) and under (side 2) surfaces of the pillow recovered from the Øksnes grave. The designations of upper and under pillow surfaces refer to the orientation of the pillow in the shipping package.

\begin{tabular}{|c|c|c|c|c|}
\hline \multirow[b]{2}{*}{ Sample } & \multicolumn{4}{|c|}{ Avian taxa identified in microscopic examination } \\
\hline & Order & Family & Genus & Bird group \\
\hline \multicolumn{5}{|c|}{ Side 1 (upper): } \\
\hline 1 & Charadriiformes & Laridae & Larus & gull \\
\hline 2 & Charadriiformes & Laridae & Larus & gull \\
\hline 3 & Charadriiformes & Laridae & Larus & gull \\
\hline \multirow[t]{2}{*}{4} & Charadriiformes & Laridae & Larus & gull \\
\hline & Suliformes & Phalacrocoracidae & Phalacrocorax & cormorant \\
\hline 5 & Charadriiformes & Laridae & Larus & gull \\
\hline \multirow[t]{2}{*}{6} & Charadriiformes & Laridae & Larus & gull \\
\hline & Anseriformes & Anatidae & Somateria & eider \\
\hline \multicolumn{5}{|c|}{ Side 2 (under): } \\
\hline 7 & Suliformes & Phalacrocoracidae & Phalacrocorax & cormorant \\
\hline \multirow[t]{2}{*}{8} & Charadriiformes & Laridae & Larus & gull \\
\hline & Suliformes & Phalacrocoracidae & Phalacrocorax & cormorant \\
\hline 9 & Charadriiformes & Laridae & Larus & gull \\
\hline 10 & Charadriiformes & Laridae & Larus & gull \\
\hline \multirow[t]{2}{*}{11} & Charadriiformes & Laridae & Larus & gull \\
\hline & Suliformes & Phalacrocoracidae & Phalacrocorax & cormorant \\
\hline 12 & Charadriiformes & Laridae & Larus & gull \\
\hline
\end{tabular}

diagnostic whole or partial pennaceous feathers of gulls in this sample for museum specimen comparison. The gull feathers used to make this pillow likely came from one or more of the "white-headed" gulls that occur in the region.

\section{DISCUSSION}

\section{Iron Age Boat Graves and Feather Remains}

Boat burials represent a widespread and important source of archaeological information in the Scandinavian Iron Age and are most common during the Viking Age (Müller-Wille, 1974). Boat burials are most often covered by a mound, and contents (in addition to boat remains) are often limited to iron rivets and human skeletal evidence. They may also contain animal remains, most commonly horse and dog, and a wide variety of grave goods such as weapons, ornaments, and different types of tools and equipment. Boat graves in northern Norway are restricted to inhumation burials from coastal locations in Nordland and southern Troms counties, where Norse settlement was predominant. Although nearly 30 boat graves have been documented containing boats from 4 to $12 \mathrm{~m}$ in length, nearly all from the Viking Age, only a handful have been excavated using modern archaeological methods. The intentional placement of the Øksnes grave in a bog is highly atypical, as only a handful of boat graves have been documented in bogs. Other boat graves in bogs from the Late Iron Age include the Holmedal ship burial and the Skarstein grave from western Norway (Shetelig and Johannesen, 1929).

Down materials were a mark of wealth and high status, and both men and women were buried with down quilts and pillows (Kaland and Martens, 2000). Although it is often assumed that these feathers are from eiders, this may not be the case, as is demonstrated in this study.
Pillows and quilts of feathers and down have been found in a number of high-status graves from the Viking Age (see Berglund, 2009). Objects with feather stuffing in highstatus graves are often associated with precious clothing and costly textiles: an example is the large construction of down and textiles in the grave chamber of the Oseberg ship burial (Vedeler, 2014). Other high-status graves with feather and down include the Gokstad ship burial and the Grønhaug grave mound in Norway and the Jellinge and Mamman burials in Denmark (Shetelig, 1912). Imprints of feathers on iron artifacts also provide evidence for the presence of feather-filled grave goods in Iron Age graves.

Species identification of bird remains found in Viking Age burials, however, has not been fully explored. Apart from the identification of duck feathers in several graves and the commonly assumed presence of eiderdown, identification of feathers has rarely been attempted. Although Bruce-Mitford (1975) describes a "goose down" pillow from the 7th century Sutton Hoo ship burial, there is no indication of how those feathers were identified. He even reports that some feathers were sent to the British Museum of Natural History, where Mr. G.S. Cowles reported that they came from "an adult bird, not down, but no further identification was possible" (Bruce-Mitford, 1975:124). Although we were able to identify multiple avian taxa from the pillow fill sub-sample here, a detailed study of the complete item may reveal additional avian taxa and more information on total species composition.

\section{Seabird Exploitation}

Given the apparent exclusive use of bird feathers from sea-dwelling birds in the Øksnes pillow stuffing, a brief review of the important role played by these birds in the Iron Age is useful. Gull and other seabird population densities are known to be among the largest in the world in 

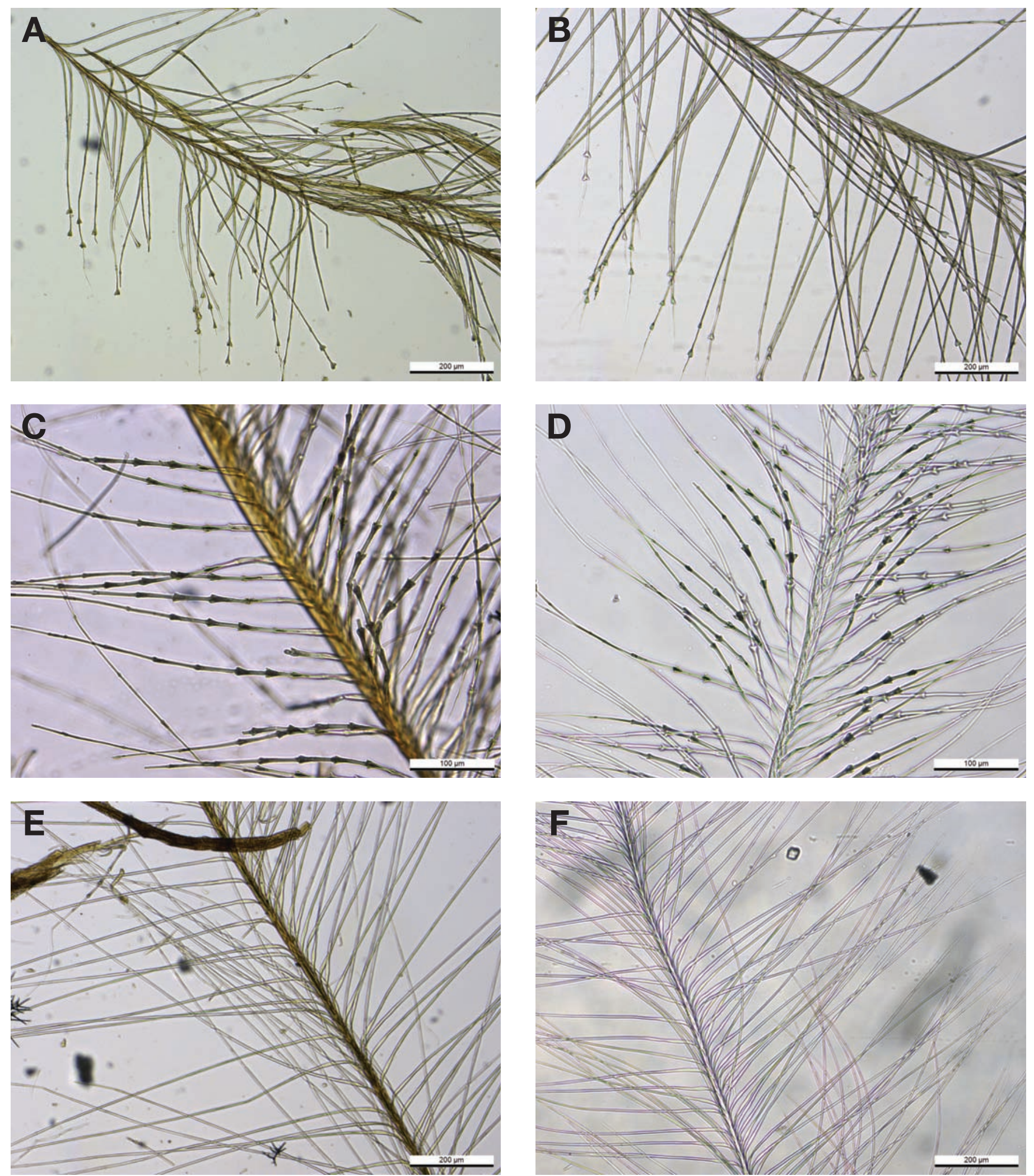

FIG 5. Photomicrographs of downy (plumulaceous) barbs of feather samples from the Øksnes pillow compared to known reference microslides of similar species. A: pillow sample showing triangular-shaped distal nodes most similar to B: Common Eider (Somateria mollissima); C: pillow sample showing expanded, pigmented basal nodes typical of gulls (Laridae); D: e.g., Herring Gull (Larus argentatus); E: pillow sample showing simplified, unexpanded nodes, typical of cormorants (Phalacrocoracidae); F: e.g., Great Cormorant (Phalacrocorax carbo).

Norway because of productive waters and adequate nesting sites (Barrett et al., 2006). Large-scale bird distributions are known to have been similar through recent historical times, so it is expected that bird densities were at least the 


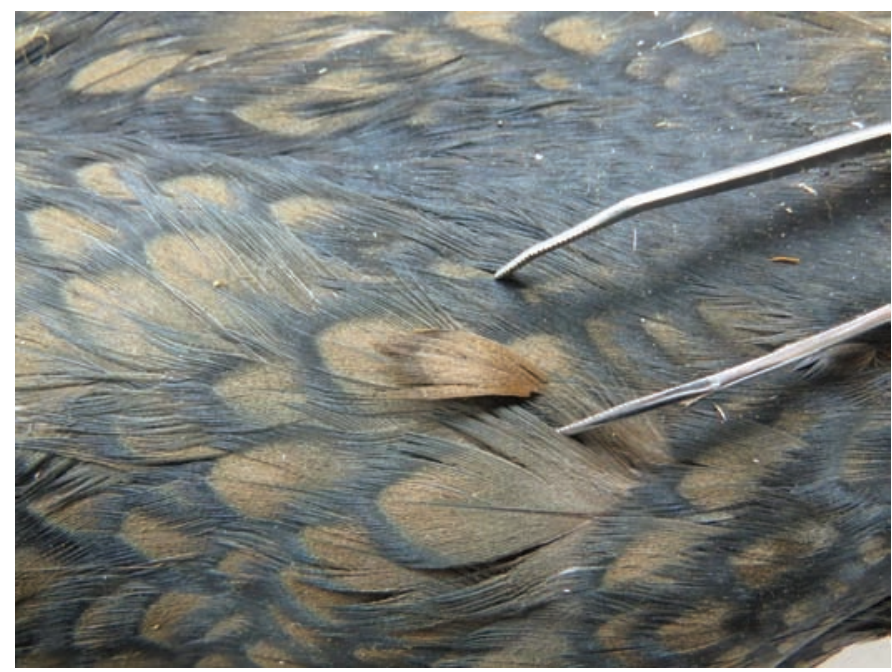

FIG. 6. Photograph of distal pennaceous feather fragment sample (middle at forceps) compared to a museum voucher specimen of Great Cormorant (Phalacrocorax carbo).

same during the Viking Age as in modern times, making it fairly easy to obtain gull species for human use. Given the vast population densities of gulls and other seabirds in northern Norway, it may not seem unusual that gull and Great Cormorant feathers were used in the making of this pillow; until now, however, these feathers have never been reported or documented as species used in Viking Age pillow making.

Thirteenth-century Norse sagas report the collecting of eider duck and goose down as a profitable trade item from Greenland and other North Atlantic regions. The Norse "cultivated" down for clothing and duvets by constructing small bird-sized boxes with upright rock slabs. Eiders preferred these cozy shelters to wind-blown boulders and lined them with fluffy down plucked from their breasts, making it possible to reap several "harvests" from each nest during the laying season. Traditional exploitation of seabirds for food and feathers is well documented in the islands of the North Atlantic and coastal Norway (Shrubb, 2013). Feathers were traditionally regarded as more valuable than meat for some seabird species, such as puffins, fulmars, and gannets, in the North Atlantic (Shrubb, 2013). The right to collect feathers, down, and eggs on so-called bird islands (fugleveer) in northern Norway has been taxed since the Iron Age, and feathers and down were commonly used for tax payments. The earliest known record of this practice is the AD 890 account to King Alfred of England by the northern Norwegian Viking chieftain Ohthere, who reported payment of taxes by the Sámi with feathers and down (Bately and Englert, 2007).

Seabirds were important in Viking life for both fresh and preserved food, and feathers and down were used for bedding and clothing. There is abundant archaeological evidence for the consumption of seabird species from coastal Norway since the Stone Age, and a recent overview of coastal settlement sites from the Helgeland region of northern Norway records at least 30 different species (Meland,
2013). The most frequently occurring species are European Shag, eiders, Great Black-backed Gull, Great Auk (now extinct), puffins, and guillemots. Cormorant species are particularly abundant in a number of the faunal assemblages. In an Iron Age settlement mound not far from Øksnes, at Bleik on the island of Andøya, with occupation from ca. AD 200 to 900 , birds represented $30 \%$ of the identifiable bone midden (Jørgensen, 1984). Sea-dwelling birds accounted for nearly all of the 25 bird species identified, with gulls and the Northern Fulmar (Fulmarus glacialis) being the most common. Five of the eight gull species within the genus Larus that occur in northern Norway were represented (Jørgensen, 1984).

\section{The Social Context of the Øksnes Grave}

In contrast to the documented occurrence of feathers and down in high-status graves, the pillow with feather stuffing from Øksnes is more suggestive of an everyday item, potentially owned by the deceased, that had been used for some time before being placed in the grave. The use of a common, coarsely woven wool textile for a pillow cover, and pillow fill in which gull feathers were predominant, along with a lesser quantity of Great Cormorant and sea duck feathers, may be indicators of a mundane domestic context rather than the luxury goods typical of a high-status grave. The potential presence of a cowhide in which the interred individual was wrapped has, to our knowledge, no existing parallels from Norwegian Iron Age boat graves and further supports a more commonplace social context rather than high status. When viewed as a whole, the Øksnes grave good assemblage, including the axe head, pillow with feather stuffing, and a probable cowhide, is not indicative of high status, and objects commonly found in high-status graves, such as weapons and costly goods, are lacking.

The boat in which the body was placed is not particularly distinctive or valuable and was most likely used for fishing and commonplace related tasks. Whether constructed by the Sámi or a hybridized product from a mixed Norse and Sámi cultural context, the vessel does not appear to have represented an object signifying interment of an individual of notably high status.

\section{ACKNOWLEDGEMENTS}

Animal hair was identified at the laboratory of the Department of Archaeology, University of Helsinki, by Tuija Kirkinen, who kindly gave us permission to cite her preliminary results. The Feather Identification Lab, Smithsonian Institution, is funded through interagency agreements with the U.S. military and the Federal Aviation Administration. Sally Bensusen illustrated the feather figure. The map and pillow photos were provided by Adnan Icagic, and the grave photos, by T. Soot-Ryan. Smithsonian Institution Libraries assisted with interlibrary loans. All of the molecular laboratory work was conducted by Faridah Dahlan, with the support of the facilities of the Laboratories of 
Analytical Biology, National Museum of Natural History. Sergei Drovetski translated the Russian abstract. We thank W. Fitzhugh for comments on an early version of the manuscript.

\section{REFERENCES}

Barrett, R.T., Lorentsen, S.-H., and Anker-Nilssen, T. 2006. The status of breeding seabirds in mainland Norway. Atlantic Seabirds 8(3):97-126.

Bately, J., and Englert, A., eds. 2007. Ohthere's voyages: A late 9 th century account of voyages along the coasts of Norway and Denmark and its cultural context. Maritime Culture of the North 1. Roskilde, Denmark: Viking Ship Museum. 216 p.

Berglund, B. 2009. Fugela Feđerum in archaeological perspective - Eider down as a trade commodity in prehistoric northern Europe. Acta Borealia 26(2):119-135.

Braun, B., ed. 1995. Arts of the Amazon. London: Thames and Hudson Ltd. 128 p.

Bruce-Mitford, R.L.S. 1975. The Sutton Hoo ship-burial: Excavations, background, the ship, dating and inventory, Vol. 1. London: British Museum Publications. 792 p.

Del Hoyo, J., Elliott, A., and Sargatal, J. eds. 1996. Handbook of the birds of the world, Vol. 3: Hoatzin to Auks. Barcelona: Lynx Edicions.

Dove, C.J. 1998. Feather evidence helps clarify locality of anthropological artifacts in the Museum of Mankind. Pacific Studies 21(3):73-85.

- 2000. A descriptive and phylogenetic analysis of plumulaceous feather characters in Charadriiformes. Ornithological Monographs 51. American Ornithologists' Union. 163 p.

Dove, C.J., and Agreda, A. 2007. Differences in plumulaceous feather characters of dabbling and diving ducks. The Condor 109(1):192-199.

http://dx.doi.org/10.1650/0010-5422(2007)109[192:DIPFCO]2. $0 . \mathrm{CO} ; 2$

Dove, C.J., and Peurach, S.C. 2002. Microscopic analysis of feather and hair fragments associated with human mummified remains from Kagamil Island, Alaska. In: Frohlich, B., Harper, A.B., and Gilberg, R., eds. To the Aleutians and beyond: The anthropology of William S. Laughlin. Publications of The National Museum Ethnographical Series, Vol. 20. Copenhagen: The National Museum of Denmark. 51-62.

Dove, C.J., Hare, P.G., and Heacker, M. 2005. Identification of ancient feather fragments found in melting alpine ice patches in southern Yukon. Arctic 58(1):38-43.

http://dx.doi.org/10.14430/arctic387

Gjessing, G. 1941. Båtfunnene fra Bårset og Øksnes: To nordnorske jernalderfunn [Boat finds from Bårset and Øksnes: Two Iron Age sites from northern Norway]. Tromsø Museums Årshefter, Kulturhistorisk avd. nr. 8, Vol. 58.

Hansen, L.I., and Olsen, B. 2014. Hunters in transition: An outline of early Sámi history. The Northern World: North Europe and the Baltic c. 400-1700 AD, Vol. 63. Leiden: Brill.

Jørgensen, R. 1984. Bleik-en økonomisk/økologisk studie av grunnlaget for jernaldergården på Andøya i Nordland
[Bleik-An economic/ecological study of the foundation of the Iron Age farm on Andøya in Nordland]. Unpubl. Master's thesis in Archaeology, University of Tromsø.

Kaland, S.H.H., and Martens, I. 2000. Farming and daily life. In: Fitzhugh, W., and Ward, E.I., eds. Vikings: The North Atlantic saga. Washington, D.C.: Smithsonian Institution Press and National Museum of Natural History. 42-54.

Kirkinen, T. 2015. Preliminary report on the identification of animal hair from the Øksnes boat burial. Unpubl. report, Topographic Archive, Tromsø University Museum, Department of Cultural Sciences, University of Tromsø, N-9037 Tromsø, Norway.

Meland, A.-K. 2013. Sjøfugl som matresssurs på Helgelandskysten - fra yngre steinalder til middelalder [Seabirds as a food source on the coast of Helgeland - from the younger Stone Age to the Middle Ages]. Unpubl. Master's thesis in Archaeology, Institutt for historiske studier, Norges TekniskNaturvitenskapelig Universitetet.

Müller-Wille, M. 1974. Boat-graves in northern Europe. International Journal of Nautical Archaeology and Underwater Exploration 3(2):187-204.

Rabineau, P. 1980. Feather arts: Beauty, wealth, and spirit from five continents. Chicago: Field Museum of Natural History.

Rogers, J.D., Dove, C.J., Heacker, M., and Graves, G.R. 2002. Identification of feathers in textiles from the Craig Mound at Spiro, Oklahoma. Southwestern Archeology 21(2):245-251.

Shetelig, H. 1912. Vestlandske graver fra jernalderen [Graves from western Norway in the Iron Age]. Bergens Museums Skrifter, Ny Række II Nr. 1.

Shetelig, H., and Johannesen, F. 1929. Kvalsundfundet og andre norske myrfund av fartøier [The Kvalsund find and other Norwegian bog discoveries of ships]. Bergen Museums Skrifter, Ny Række II Nr. 3.

Shrubb, M. 2013. Feasting, fowling and feathers: A history of the exploitation of wild birds. Poyser Monographs 391. London: T \& AD Poyser.

Thingnæs, S. 2014. Rapport fra tekstilteknisk analyse for Tromsø Museum 3.-4. november 2014 [Report on technical textile analysis from the Tromsø Museum 3-4 November 2014]. Unpubl. report, Topographic Archive, Tromsø University Museum, Department of Cultural Sciences, University of Tromsø, N-9037 Tromsø, Norway.

Vedeler, M. 2014. The textile interior in the Oseberg burial chamber. In: Bergerbrant, S., and Fossøy, S.H., eds. A stitch in time: Essays in honour of Lise Bender Jørgensen. Gotarc Series A. Gothenburg Archaeological Studies, No. 4. Gothenburg, Sweden: Department of Historical Studies, University of Gothenburg. 281-300.

Westerdahl, C. 2010. Ancient boats of the Sami in Fennoscandia: A brief survey with a focus on the inland environment, in particular those of the Forest Sami. In: Westerdahl, C., ed. A circumpolar reappraisal: The legacy of Gutorm Gjessing (1906-1979). BAR International Series 2154. Oxford: Archaeopress. 329-348.

Wickler, S. 2010. Visualizing Sami waterscapes in northern Norway from an archaeological perspective. In: Westerdahl, C., ed. A circumpolar reappraisal: The legacy of Gutorm Gjessing (1906-1979). BAR International Series 2154. Oxford: Archaeopress. 349-361. 